\title{
KAIZEN AND LEAN IMPLEMENTATION IN PHARMACEUTICAL INDUSTRIES: A REVIEW
}

\author{
SRINIVASAN G*, SHAH N \\ Department of Pharmaceutics, Vivekanand Education Society's College of Pharmacy, Hashu Advani Memorial Complex, Chembur (E), \\ Affiliated to University of Mumbai, Mumbai - 400 074, Maharashtra, India. Email: ganga.srinivasan@ves.ac.in
}

Received: 11 January 2018, Revised and Accepted: 09 May 2018

\begin{abstract}
Kaizen is one of the most commonly used words in all kind of industries. It has been implemented in organizations around the world as a way to improve production values while also improving employee morale and safety. The kaizen process brings about improvements that are small and incremental, and significant results can be seen only after a certain period of time. Many organizations across the world have adopted kaizen management philosophy and have successfully increased the efficiency of their end-to-end supply chains. With a focus on quality and regulatory compliance that are getting stringent day by day, pharmaceutical companies have been adopting these new strategies. This review focuses on basic aspects of Kaizen and Lean implementation and highlights few examples from pharmaceutical industry.
\end{abstract}

Keywords: Muda, Lean management, Kaizen 5S, Plan-do-check-act/standardize-do-check-act cycle.

(C) 2018 The Authors. Published by Innovare Academic Sciences Pvt Ltd. This is an open access article under the CC BY license (http://creativecommons. org/licenses/by/4. 0/) DOI: http://dx.doi.org/10.22159/ajpcr.2018.v11i7.24722

\section{INTRODUCTION}

The word kaizen is derived from two Japanese words "Kai" which means change and "Zen" which means good, so kaizen means to change for the good [1]. The main focus of kaizen is to break down complex processes into subprocesses and then gradually to improve them. It is a strategy for continuous improvement by making small increments to make the process more efficient and adaptable [2]. In the United States (US), kaizen is often synonymous with "Kaizen Blitz" or "Kaizen event" [3].

The strategy to involve workers at all levels and functions in an organization to address a problem or improve a process is what kaizen aims at. It includes the use of analytical techniques such as value stream mapping (VSM) and Five-S framework to identify opportunities and to identify and eliminate wastes and errors at earliest [4]. In short, it rapidly implements work cells, improves setups, or streamlines processes [3]. The concept of Kaizen is deeply ingrained in the minds of employees at all levels in Japan. Many times, they do not realize that their thinking is based on kaizen strategy for continuous improvement [5].

\section{THE OBJECTIVES OF KAIZEN [5]}

- Kaizen aims on establishing acceptable working culture/environment as that encourages feedback from employees who continuously try to improve their jobs or process.

- Determine the capital cost of projects.

- To involve slow but steady incremental improvements.

- To involve every employee and develop products as per the demands of customer.

- To create defect-free products.

\section{FEATURES OF KAIZEN [6]}

- It is widely applicable throughout different markets.

- Although slow in giving outcomes, it is highly effective and result oriented.

- It is a learning experience for an entire organization that adopts kaizen.

- It is a team-based approach and requires collaborative efforts.

\section{BASIC PRINCIPLES OF KAIZEN [7]}

1. Major focus on customer.

2. Making continuous improvements.
3. Acknowledging the problems openly

4. Create environment for teamwork.

5. Development of self-discipline.

6. Giving constant feedback to employees.

7. Promoting development of employees.

Of this foundation, three key factors arise as follows [8]:

1. Elimination of waste (Muda).

2. The Five-S frameworks or housekeeping.

3. Standardization.

According to Imai, a guru in these management philosophies and practices, the management and employees must work together to fulfill the requirements for each category[9].

\section{Elimination of waste (Muda)}

Muda in Japanese means waste. Work is a series of value adding activities, from raw materials, ending to a final product. Muda is any non-value-added process at any given stage of production [10].

In Kaizen philosophy, the aim is to eliminate the seven types of Muda, i.e., 7 deadly wastes that are as follows $[10,11]$ :

1. Overproduction - Producing more than production schedule

2. Inventory - Too much material before initiation of process.

3. Defects - Material and labor are wasted; capacity is lost at bottleneck.

4. Motion - to get parts because of space taken by high work in process.

5. Processing - Protecting parts for transport to another process.

6. Waiting - Poor balance of work; operator attention time.

7. Transportation - Long moves; re-stacking; pick up/put down.

Overproduction [12]

- It means to manufacture a product more than its actual requirement.

- Overproduction leads to high storage costs, and defects are difficult to detect.

- To avoid this, the production should be scheduled and only what can be immediately sold or shipped should be produced.

Waiting [13]

- It may involve waiting for personnel, data, equipment, or a part of equipment. 
- This can occur when flow of materials through supply chain is poor, long production runs and large distances between work centers.

- This can be avoided by linking processes together so that one process feeds directly into another, thus reducing waiting.

\section{Transporting [13]}

- It is a cost incurred when the product is transferred between processes. Transporting does not add any value to the product.

- Quality can be deteriorated because of excessive movement and handling.

- This waste can be reduced by mapping product flows that are easier to visualize.

\section{Inappropriate processing}

- It is the use of expensive equipment where process can be completed by the use of simpler devices.

- This often results in high costs of production and poor plant layout.

- Replacing complex steps with simpler ones or combining processing steps can greatly reduce the waste of inappropriate processing.

- The lean implementation by Toyota is a classic example of techniques to avoid inappropriate processing [14]

\section{Unnecessary inventory}

- Overproduction of materials, high waiting time, and procuring unwanted raw materials can lead to unnecessary inventory.

- This tends to hide problems on the plant floor. To improve operating performance, such problems must be identified and resolved.

- Excess inventory can lead to increased storage time, and productive floor space is consumed [15].

- A seamless flow between work centers can help in avoiding buildup of excess inventory.

\section{Unnecessary/excess motion [4]}

- Related to ergonomics, this waste can be seen at every stage of a process. It can also lead to health and safety issue which can become a problem for organizations given the stringent safety standards of current times.

- To avoid this, jobs involving excessive motion should be redesigned and improved with involvement of plant operators.

\section{Defects [16]}

- This can result in reprocessing which is a tremendous cost to organizations because of quarantining inventory, reinspecting, rescheduling, and capacity loss.

- Many times, a significant proportion of total production cost is the cost of defects.

- Defects can be reduced only through employee involvement.

\section{Five-S Framework}

In Japanese, "Gemba" means workplace. The Five-S framework is the process of managing "Gemba" for improvement. The value is added to any product or service before passing them to next process using the $5 \mathrm{~S}$ methodology [15]. The "Five-S" is derived from first letter of Japanese words referring to five practices, namely, seiri (organization), seiton (tidiness), seiso (Purity), seiketsu (cleanliness), and shitsuke (discipline) (Fig. 1) [17]. They provide significant insight in the orderliness of work area. These evaluations aid in understanding what employees feel about their products or services, their organizations, and themselves. The evaluations can be carried out by preparing checklists for production and nonproduction areas that cover various aspects of cleanliness, safety, and arrangement of workplaces [18].

\section{Standardization}

Even though standards are set by management, they must be changed with the change in work environment. Improvement can be achieved by periodic reviewing of standards, collection, and analysis of data on defects and encouraging teams to conduct problem-solving activities [19]. When standards are in place, workers can immediately detect a problem if there is any deviation. Then, the employees can either review and modify the standard or correct the deviation. This is a never-ending process better explained by the plan-do-check-act (PDCA) cycle, known as Deming cycle [20].

To improve on a standard, it is first important to set a standard. For every aspect in an organization, be it a process, product, personnel, and team leaders, there must be a precise standard of evaluation set [21]. Kaizen aims for constant improvement of these standards. In onepoint standardization, each worker performs many tasks, of which only one task needs to be standardized. This one-point standard is often displayed in the workplace so that the worker is always mindful of it. Once that particular standard is followed meticulously, another standard, if required, can be added. Standardization is a way of spreading the benefits of improvement throughout the organization [22]. In a disciplined environment, everyone, including management, is mindful of those standards [20].

Standardization process is a very important one that has few key features, presented below [22]:

- Represent the best, easiest, and safest way to do the job,

- Offer the best way to preserve know-how and expertise,

- Provide a way to measure performance,

- Show the relationship between cause and effect,

- Provide a basis for both maintenance and improvement,

- Provide objectives and indicate training goals,

- Provide a basis for training

- Create a basis for auditing or diagnosis, and

- It provides sources to prevent recurrence of errors and consequently minimize variability.

\section{MAJOR KAIZEN CONCEPTS [23]}

Management must emphasize on learning and implementing certain basic concepts and systems to realize kaizen strategy:

1. Kaizen and management.

2. Process versus result

3. Following the PDCA/standardize-do-check-act (SDCA) cycles.

4. Putting quality first.

5. Speak with data.

6. The next process is the customer.

It is the responsibility of top management to clearly put forth these concepts and systems to their employees. It should demonstrate leadership by practicing kaizen within its department and then establish an implementation schedule for whole organization [24].

\section{Kaizen and management}

In the kaizen context, management has two major functions: Maintenance and improvement (Fig. 2). Maintenance refers to activities directed toward maintaining current technological, managerial, and operating standards and upholding such standards through training and discipline. Under this function, management is responsible to perform its assigned tasks so that everybody can follow standard operating procedures and maintain the same standards for every production batch [25]. Improvement, on the other hand, refers to activities focused toward enhancing current standards. Management always aims to maintain and improve standards. Improvement can be classified as kaizen and innovation (Fig. 3). Small improvements because of ongoing efforts are what kaizen is all about [26]. Innovation, however, involves large investment of resources in new technology or equipment for drastic improvements. Due to their fascination with innovation, kaizen and its long-term benefits are often overlooked by Western managers. While innovation asks for large investments, kaizen emphasizes on a low-cost approach to improvement based on human efforts, communication, training, teamwork, involvement, and selfdiscipline [9]. 


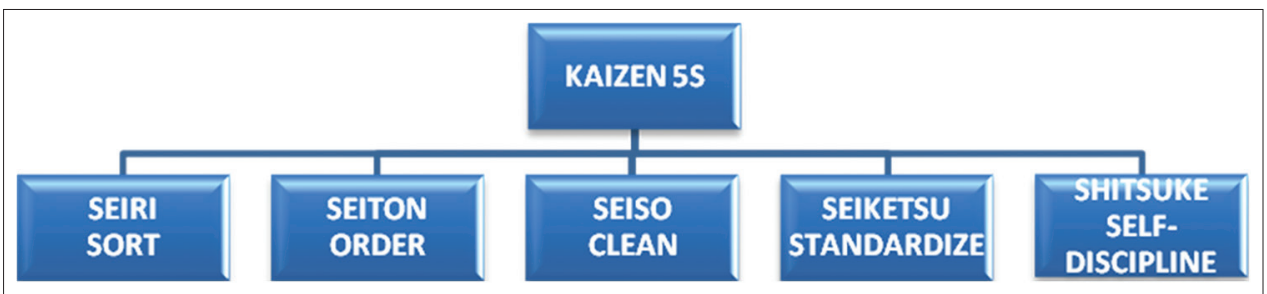

Fig. 1: Kaizen-5S

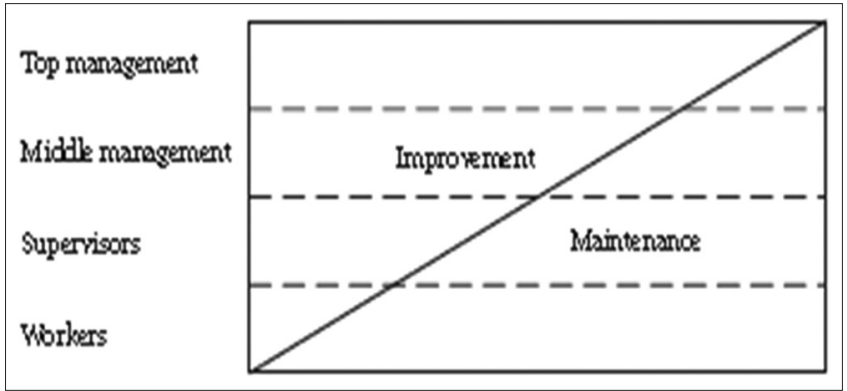

Fig. 2: Japanese perceptions of job functions

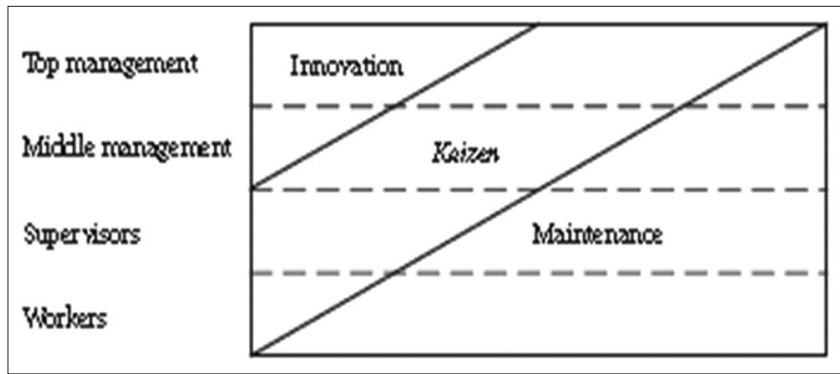

Fig. 3: Improvement broken down into innovation and kaizen



Fig. 4: Plan-do-check-act cycle

\section{Process versus result}

Process-based errors lead to failure in achieving planned results. Kaizen preaches process-oriented thinking as their improvement ultimately improves the results [27]. As stated before, kaizen focuses on human efforts in contrast to result-based thinking of the West. Using various strategies associated with kaizen, namely, the PDCA cycle; the SDCA cycle; quality, cost, and delivery (QCD); justin-time (JIT); total quality management; JIT; and total productive maintenance (TPM), a process-oriented approach should be applied to achieve target results. Here, the commitment and involvement of top management in kaizen implementation play an important role [28].

\section{The PDCA/SDCA cycles}

The PDCA stands for "PDCA," which is the first step in kaizen process. The PDCA cycle ensures the continuity of kaizen in pursuing a policy. It is also known as Shewhart cycle, Demming cycle, or PDCA (Fig. 4) [29].

Plan - to establish a target for improvement and devising action plans to achieve that target.

Do - to implement the established plan.

Check - to inspect the implementation of plan as per decided timelines and targeted outcomes.

Act - to perform new standardized procedures, to prevent recurrence of errors, or to set targets for improvisation.

As any new work process can be difficult to follow in the beginning, the "SDCA" cycle must be followed to stabilize a process before starting to work on PDCA cycle. SDCA primarily deals with maintenance while PDCA deals with improvement; these become the two major responsibilities of management [23].

\section{Putting quality first}

Quality should always be given highest priority in comparison to price and delivery aspects. Lack of quality in product or service can create a bad reputation for any company no matter how attractive prices are $\mathrm{Al}$ Smadi [30]. Lot of management commitment is required to maintain quality because managers are often tempted to make compromises in meeting delivery requirements or cutting costs. In doing so, they risk sacrificing not only quality but also the life of the business [9].

\section{Speak with data}

In kaizen, it is important to understand a problem correctly to solve it. The relevant data have to be gathered and analyzed to initiate the problem-solving process. This helps in understanding where the focus is and also serves as a starting point for improvement [31].

\section{The next process is the customer [32]}

All work is a series of processes, and each process has its supplier as well as a customer. A material or a piece of information provided by process $\mathrm{A}$ (supplier) is worked on and improved in process $\mathrm{B}$ and then sent on to process C, i.e., customer. The axiom "the next process is the customer" refers to two types of customers: Internal (within the company) and external (out in the market). Most people working in an organization deal with internal customers. Hence, they must commit to never provide inaccurate data or defective parts to people involved in next process. When the overall process is carried out in this manner, the end customer in the market surely receives product or service of high quality.

\section{ASPECTS OF KAIZEN}

\section{Gemba Kaizen}

"Gemba" means the place where the products are made, so Gemba Kaizen is to make continuous improvement at the location where all the action is going on to make the organization better [33]. 


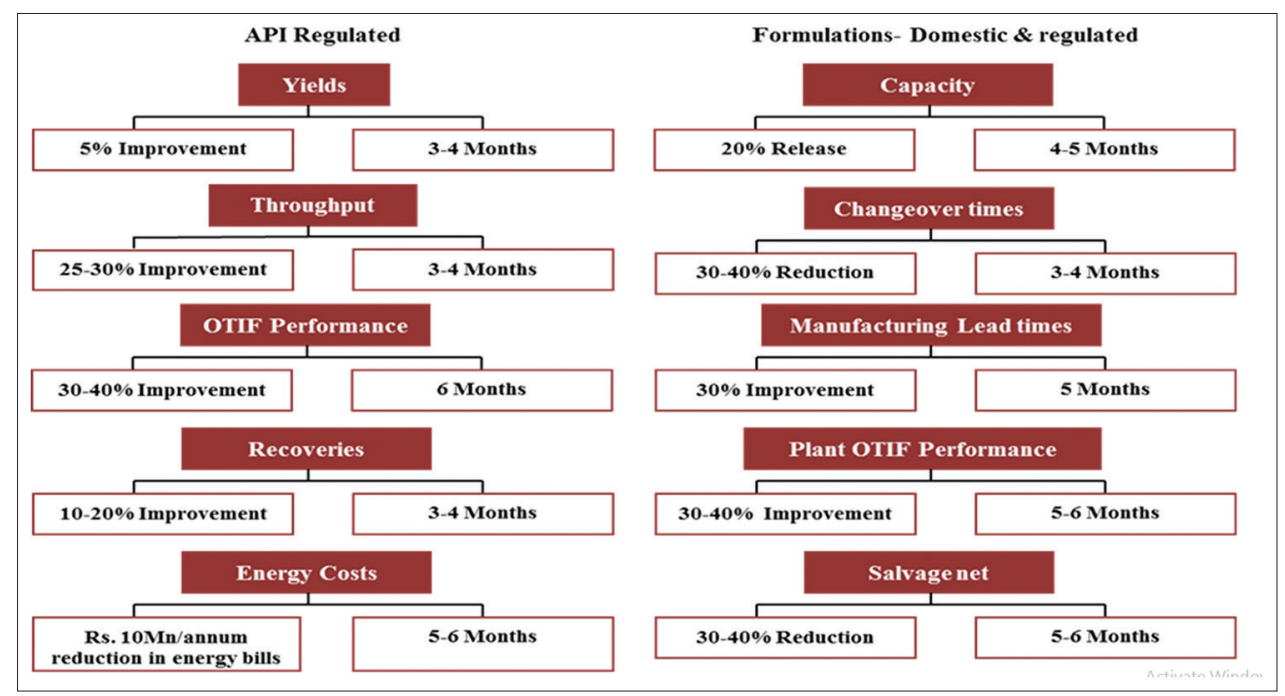

Fig. 5: Kaizen effect on both API regulated and formulation domestic and regulated field

\section{Kaizen Blitz}

The blitz means a focused, intense, short-term event to improve a localized process with a basic concept of identifying and quickly removing waste. Kaizen Blitz involves training of personnel followed by the analysis, design, and rearrangement, if required, of a process or location. A consultant often conducts this event over a period of 2-5 days. A Kaizen Blitz is a focused activity on a particular process or activity for rapid improvement [34].

\section{Quick and easy or mini kaizen}

It is used to bring minute improvements in conscious and sub-conscious thinking of employees [35].

Important characteristics of Mini Kaizen include [36]:

- Permanent changes in method of routine processes.

- Continuous flow.

- Immediate, local implementation.

- It is a quick and simple process.

\section{Lean Kaizen}

It helps the organization to reduce wastes, excess costs, and nonvalue added activities. This results in the development of a company in market in terms of competition, agility, and market responsiveness. Lean Kaizen is a systematic approach to identify and eliminate waste by continuous improvement [37].

\section{Need of lean [33]}

Lean is, especially, important today as a winning strategy. Some key reasons are as follows:

- To compete effectively in today's global economy.

- Customer pressure for price reductions.

- Fast-paced technological changes.

- Continued focus by the marketplace on QCD.

- Quality standards established by regulatory agencies worldwide.

- High customer expectations.

- Need to develop standardized process to obtain uniform high-quality outcomes.

\section{VSM}

It is the first step that has to be carried out toward lean implementation. Value stream means to a collection of all activities that are essential in the development of a product or group of products using similar resources, from raw material to the end customers. The activities can be value added as well as no value added [38]. VSM involves documenting the correlation between the production and the controls required to manage various processes in production and related information. VSM documents the basic flow of product, material inventory, and reasons for the movement of material from one key process to next [39]. Once the mapping is done, basic idea is to identify the wastes and gaps in system and make modifications to reduce these issues. VSM can be carried out for practically any business activity and expanded upstream or downstream. This tool highlights process inefficiencies, transactional, and communication mismatches and also guides about the improvement [38].

\section{KAIZEN IMPLEMENTATION IN PHARMACEUTICAL INDUSTRY}

The Pharmaceutical Industry has historically concentrated on Research and Development and Marketing while manufacturing was regarded merely as a regulatory compliance requisite. Moreover, the pharmaceutical companies believed that Lean principles were not relevant to their environment [40]. As pharmaceutical industry is highly regulated, the principles of process flow optimization, built-in quality, reduction in equipment setup time, and process management were not implemented as easily as in other manufacturing industries [41].

Pharmaceutical industry requires a shift in thinking, due to following factors [42]:

- Increasing buyer-driven pressure on pricing.

- Increasing variability in demand.

- Higher heterogeneity of customer preferences.

Furthermore, pharmaceutical industry has high working capital. Hence, to gain competitive advantage through their processes, top pharmaceutical companies have started to work with the Kaizen Institute. However, the industry still lags behind with regard to lean thinking [43].

Globally, pharmaceutical companies have shown improvement in the overall business performance after lean implementation. The savings achieved are outstanding and appear to be higher than in other discrete manufacturing industries, such as the car industry. Quality improvement, better use of assets, optimization of flow, higher flexibility, and a sustainable and efficient continuous improvement strategy are some of the main points that the industry needs to focus on [44,45]. The Kaizen management system model with its various elements, such as flow management, TPM, quality control, service management and change management that provides perfect solutions for every company [46]. As the methods and training maintain international standards, kaizen approach can be easily implemented on a global scale [47].

\section{Sanofi-Aventis Deutschland GmbH}

Sanofi Aventis Group began implementing Kaizen in 2005 at their production plant located in Frankfurt, Germany, with initial focus on $5 \mathrm{~S}$ activities. A second pilot was initiated 2 years later in another office. In November 2007, after impressive results with these pilot 
schemes, the management decided to rollout Kaizen across the whole site. Before introducing Kaizen activities, the plant was in dubious state with oil leaking from machines, missing machine parts, etc. Through $5 \mathrm{~S}$ workshops and TPM, the plant's performance improved markedly. The main administrative issues were search times, ergonomics, transparency, and long lead times. The 5S framework and value stream addressed these issues and aided in achieving greater efficiency in their offices.

All employees were involved, and they contributed many creative, intelligent solutions to improve their working environment. The management team believes that these activities will provide a solid, long-term foundation for the company. Kaizen proved to be a powerful team building activity that united all employees with a common goal of continuous improvement. It also significantly reduced the costs involved in manufacturing and supply [48].

\section{Boehringer Ingelheim}

It is the first Pharmaceuticals Company to receive the "5S Best in Class" Award. The certificate was presented by Masaaki Imai on March 30, 2009. Initially, the company introduced $5 S$ to increase employees' awareness of process optimization.

Kaizen implementation in Indian Pharma industry is at a significant phase. It is achieving a distinctive position in the international market with generics, contract research, and clinical trials. With the increase in market share, companies face increased competition on the grounds of speed to market, cost competitiveness, quality of products, customeroriented approaches in development, and effective distribution. Kaizen aids pharmaceutical industries in evaluating the ways and means to control supply chain costs and enhance their processing efficiency [48].

Over the past 20 years, various organizations across the world started to adopt lean management philosophy to enhance their quality and effectiveness of supply chains [49]. With quality and regulatory compliance always being the major focus, adopting new approaches to improve operations have always been a priority for the pharmaceutical industry. Supply chain and operational cost-effectiveness have also come under the focus because of increased competition and cost pressures. Many major pharmaceutical companies have adopted operation improvement initiatives in the recent years and have realized their benefits.

Initial results of lean implementation in Indian pharma [50]

Following are some case studies of Pharmaceutical Companies:

\section{Dr. Reddy's Kaizen implementation [50]}

- They undertook a company-wide constraint management initiative across various departments that included strategic planning, supply chain, marketing, metrics, finance, operations, and project management.

- This initiative helped to develop an advantage for the company by systematically synchronizing its various departments of supply chain such as research and development (R\&D), manufacturing, and distribution.

- To improve efficiency and increase the productivity of R\&D to complete projects on time, they introduced more generic drugs and APIs in the market at lower risk and investment.

- They undertook lean manufacturing initiative which focused on reduction of process variabilities to increase flexibility.

- Key part of initiative was to involve operators to carry out autonomous maintenance. This increased company's net times and decreased overall operating times by $22 \%$.

\section{Piramal health-care kaizen implementation [50]}

- To reduce expenses and cash-to-cash cycle, the company undertook a supply chain initiative in 2005 .

- They reduced their raw/packing material inventory at their overseas facilities from 22 days to 20 days in between financial years 2008 and 2009.

- They enhanced the efficiency of plant operations through various projects and initiatives.
- The oil consumption was reduced by plugging stem leakages, and the use of coal-fired boiler was optimized to maintain steam pressure at peak load.

- Piramal health care was awarded the "Healthcare and Life Science Manufacturing Supply Chain Excellence Award" during the 2008 SCM Logistics Excellence Awards for their efforts.

- It is the only Indian company to figure on iSixSigma "10 Best Places to Work for Six Sigma Professionals."

\section{Lean sigma implementation by GlaxoSmithKline (GSK) [51]}

- GSK is the second largest research-based pharmaceutical company in the world.

- In 2003, Lean Sigma program was formally adopted and customized for use in R\&D.

- The anticipated benefits were as follows:

- Process harmonization: Reduction in waste production and process inefficiency.

- Increase in productivity by higher focus on value-adding activities.

- Promoting the ideology of becoming a learning organization.

- GSK was able to achieve annualized cost saving of $£ 300$ million by 2004 through operational efficiencies.

\section{Lean manufacturing by Merck [52]}

- Merck worked with IBM global business services to implement a program of lean manufacturing and to build these process improvements into its future global ERP system. From end-to-end, rigid production practices have been replaced with flexible, demanddriven processes.

- Using VSM, the team tracked the changeover process and found that most of the waste resulted from the lengthy production process it was following, as well as improper changeover procedures.

- Using algorithms that minimized the overall effects of the changeovers, the IBM team identified the ideal manufacturing cycle, or "rhythm sequence," resulting in a 50\% reduction in changeover time on some production lines.

- Key benefits included:

- $\quad$ Up to $30 \%$ reduction in production-related inventory costs.

- Up to $20 \%$ reduction in overall operating expenses at plant level.

- Up to $50 \%$ reduction in change over procedures.

\section{CONCLUSION}

With increased regulatory compliance requirements, it is now not possible for pharmaceutical industries to sustain on huge waste generations and errors that have become common in manufacturing sector by the current operating model [53].

Like industries of other sectors, pharmaceutical companies have started embracing concepts of Kaizen and Lean Management, and their benefits are clearly visible from the case studies mentioned in the article. The current pricing and regulatory pressures, batch failures, and customer complaints have prompted Pharma companies to adopt these new strategies. They now need to combine their knowledge of science and the concepts of Kaizen and Lean Management to proactively work toward solving problems and increase their productivity.

\section{CONFLICTS OF INTEREST}

The authors declare that there are no conflicts of interest regarding the publication of this paper.

\section{AUTHORS' CONTRIBUTION}

The authors contributed equally to this work.

\section{REFERENCES}

1. Kiran DR. Chapter 22-Kaizen and Continuous Improvement. In: Guerin B, editor. Total Quality Management. Oxford, United Kingdom: Butterworth-Heinemann; 2017. p. 313-32.

2. Brunet AP, New S. Kaizen in Japan: An empirical study. Int J Oper Prod 
Manag 2003;23:1426-46. Available from: http:/www.emeraldinsight. com/doi/10.1108/01443570310506704. [Last cited on 2017 Oct 06]

3. Lee Q. All about Kaizen. Kansas City: Strategos Inc.; c2004. Available from: http://www.strategosinc.com/downloads/kaizen-dl1.pdf. [Last cited on 2017 Oct 08]

4. Van PN. Lean Manufacturing-implementation and benefit in production activities. SSRN 2015;1-11. Available from: http://www.ssrn.com/ abstract $=2555428$. [Last cited on 2017 Oct 15].

5. Moore R. Chapter 8-Kaizen. In: Total Quality Management. Burlington, USA: Elsevier Inc.; 2007. p. 159-72.

6. Karkoszka T, Honorowicz J. Kaizen philosophy a manner of continuous improvement of processes and products. J Achiev Mater Manuf Eng 2009;35:197-203. Available from: http:/www.delibra.bg.polsl.pl/ Content/35432/0000050240.pdf. [Last cited on 2017 Sep 28].

7. García JL, Rivera DG, Iniesta AA. Critical success factors for Kaizen implementation in manufacturing industries in Mexico. Int J Adv Manuf Technol 2013;68:537-45.

8. Manos A. The benefits of kaizen and kaizen events. Qual Prog 2007; $40: 47-8$

9. Imai M. Gemba Kaizen: A Commonsense Approach to a Continuous Improvement Strategy. New York: McGraw-Hill; 1997.

10. Kaizen Definition and Principles in Brief A Concept and Tool for Employees Involvement. Thessaloniki, Greece: Michaellolidis: Total Quality and Productivity Concept; 2006. p. 1-42. Available from: https://www.michailolidis.gr/pdf/KAIZEN08.pdf. [Last cited on 2017 Oct 09].

11. Pegels CC. The toyota production system-lessons for American management. Int J Oper Prod Manag 1984;4:3-11.

12. Wittenberg G. Kaizen - the many ways of getting better. Assem Autom $1994 ; 14: 12-7$

13. Flug J, Nagy P. The lean concept of waste in radiology. J Am Coll Radiol 2011;8:443-5.

14. Liker JK. The Toyota Way: Striving for Excellence. In: Netland TH, Powell DJ, editors. The Routledge Companion to Lean Management. New York, USA: Routledge; 2016. p. 9-19.

15. Hicks BJ. Lean information management: Understanding and eliminating waste. Int J Inf Manage 2007;27:233-49.

16. Melton T. The benefits of lean manufacturing: What lean thinking has to offer the process industries. Chem Eng Res Des 2005;83:662-73.

17. Titu MA, Oprean C, Grecu D. Applying the Kaizen Method and the 5S Technique in the Activity of Post-Sale Services in the KnowledgeBased Organization. Proceedings of the International Multi Conference of Engineers and Computer Scientists; Hong Kong; Reasearch Gate; 2010. p. 17-9.

18. Gupta S, Jain SK. The $5 \mathrm{~S}$ and kaizen concept for overall improvement of the organisation: A case study. Int J Lean Enterp Res 2014;1:22-40. Available from: http://www.inderscience.com/link.php?id=6280. [Last cited on 2017 Nov 02]

19. Ortiz C. All-out kaizen. Indust Eng 2006;38:30-1

20. Van Aken EM, Farris JA, Glover WJ, Letens, G. A framework for designing, managing, and improving Kaizen event programs. Int J Product Perform Manag 2010;59:641-67. Available from: http://www. emeraldinsight.com/doi/10.1108/17410401011075648. [Last cited on 2017 Nov 03].

21. Shang G, Pheng LS. Understanding the application of Kaizen methods in construction firms in China. J Technol Manag China 2013;8:18-33. Available from: http://www.emeraldinsight.com/doi/10.1108/JTMC03-2013-0018. [Last cited on 2017 Nov 03].

22. Míkva M, Prajová V, Yakimovich B, Korshunov A, Tyurin I. Standardization-one of the tools of continuous improvement. Proced Eng 2016;149:329-32.

23. Masaaki I, Bildhauser L. The Key to Japan's Competitive Success. New York: McGraw-Hill Education; 1986.

24. Bhasin S. Performance of Lean in large organizations. J Manuf Syst 2012;31:349-57.

25. Singh J, Singh H. Continuous improvement approach: Stateof-art review and future implications. Int $\mathrm{J}$ Lean Six Sigma c2012;3:88-111. Available from: http://www.emeraldinsight.com/ doi/10.1108/20401461211243694. [Last cited on 2017 Nov 15].

26. Chen JC, Li Y, Shady BD. From value stream mapping toward a lean/ sigma continuous improvement process: An industrial case study. Int J Prod Res 2010;48:1069-86.

27. Barad M. Quality-oriented Strategies. Springer Briefs Appl Sci Technol 2018;5-29.

28. Sugiyama H, Schmidt R. Realizing Continuous Improvement in Pharmaceutical Technical Operations-Business Process Model in Roche's Parenterals Production Kaiseraugst. Proceedings of the $22^{\text {nd }}$ European Symposium on Computer Aided Process Engineering; London: Elsevier; 2012. p. 17-20.

29. Ren MM, Ling N, Wei X, Fan SH. The Application of PDCA Cycle Management in Project Management. Proceedings of 2015 International Conference on Computer Science and Applications [Internet]; 2015. p. 20-2; Wuhan: Conference Publishing Services: 2015. p. 268-72. Available from: http://www.ieeexplore.ieee.org/ document/7810878/. [Last cited on 2017 Oct 09].

30. AlSmadiS. Kaizen strategy and the drive for competitiveness: Challenges and opportunities. Compet Rev 2009;19:203-11. Available from: http:// www.emeraldinsight.com/doi/10.1108/10595420910962070. [Last cited on 2017 Dec 16].

31. Lodgaard E, Ingvaldsen JA, Aschehoug S, Gamme I. Barriers to continuous improvement: Perceptions of top managers, middle managers and workers. Proced CIRP 2016;41:1119-24.

32. Imai M. Gemba Kaizen: A Commonsense Approach to a Continuous Improvement Strategy. New York: McGraw Hill Professional; 2012.

33. Levinson WA, Rerick RA. Lean Enterprise: A Synergistic Approach to Minimizing Waste. Milwaukee: ASQ Quality Press; 2002.

34. Medinilla A. Retrospectives and Kaizen Events. Agil Kaizen Manag Contin Improv Far Beyond Retrosp. Berlin, Heidelberg: Springer Berlin Heidelberg; 2014. p. 37-58.

35. Asaad MN, Saad R, Yusoff RZ. 5S, kaizen and organization performance: Examining the relationship and level of implementation using rasch model in Malaysian automotive company. Int Acad Res J Bus Technol 2015;1:214-26.

36. Kaizen What does it mean? Kansas City(MO): Strategos Inc.; c2007. Available from: http://www.strategosinc.com/kaizen.htm. [Last cited on 2018 Feb 05]

37. Wagner S. Lean transformation. Engineering 2009;294:1-10.

38. Rother M, Shook J. Learning to See: Value Stream Mapping to Add Value and Eliminate Muda. Cambridge: The Lean Enterprise Institute; 2003.

39. Singh B, Garg SK, Sharma SK. Value stream mapping: Literature review and implications for Indian industry. Int J Adv Manuf Technol 2011;53:799-809.

40. Friedli T, Basu P, Bellm D, Werani J. Leading Pharmaceutical Operational Excellence: Outstanding Practices and Cases. Heidelberg: Springer Science \& Business Media; 2013.

41. Ahmed T, Ali SM, Allama MM, Parvez MS. A Total productive maintenance (TPM) approach to improve production efficiency and development of loss structure in a pharmaceutical industry. Glob J Manag Bus Res 2010;10:186-90.

42. Politis SN, Rekkas DM. The evolution of the manufacturing science and the pharmaceutical industry. Pharm Res 2011;28:1779-81.

43. Tokyo: Kaizen Institute Ltd.; c2014. Available from: http://hk.kaizen. com/en-sectors/en-pharmaceutical.html. [Last cited on 2017 Nov 17].

44. Tokyo: Kaizen Institute Ltd.; c2014. Available from: https://in.kaizen. $\mathrm{com} / \mathrm{blog} /$ post/2014/09/08/kaizen-in-pharmaceuticals.html. [Last cited on 2017 Nov 17].

45. Singh GK, Azman KA, Hadi MA, Jaafar Z, Affandi M. Scheduled and standardised training improved employees' knowledge on good manufacturing practices (GMP). Int J Pharm Pharm Sci 2018;10:186 90.

46. Suárez-Barraza MF, Ramis-Pujol J, Kerbache L. Thoughts on kaizen and its evolution. Int J Lean Six Sigma 2011;2:288-308. Available from: http:/www.emeraldinsight.com/doi/10.1108/20401461111189407. [Last cited on 2017 Nov 29].

47. Bonaccorsi A, Carmignani G, Zammori F. Service value stream management (SVSM): Developing lean thinking in the service industry. J Serv Sci Manag 2011;4:428-39. Available from: http://www.scirp. org/journal/doi.aspx?DOI=10.4236/jssm.2011.44048. [Last cited on 2017 Dec 16]

48. Decourtye E. Operational Excellence is Indispensable. Zug, Switzerland: Kaizen Institute Consulting Group Ltd.; c2009. Available from: http://www.webcache.googleusercontent. com/search?q=eache:7eam7utlcrQJ: hk.kaizen.com/ensectors/en-pharmaceutical/file/kaizen-forum/action/download. $\mathrm{html}+\& \mathrm{~cd}=1 \& \mathrm{hl}=\mathrm{en} \& \mathrm{ct}=\mathrm{clnk} \& \mathrm{gl}=\mathrm{in}$. [Last cited on 2017 Jun 20]

49. Liker JK, Morgan JM. The Toyota way in services: The case of lean product development. Acad Manag Perspect 2006;20:5-20. Available from: http://www.amp.aom.org/cgi/doi/10.5465/AMP.2006.20591002. [Last cited on 2017 Nov 08].

50. Lean Implementation: Indian Pharmaceutical Industry. Mumbai: Organization of Pharmaceutical Producers of India; c2013. Available from: https://www.indiaoppi.com/sites/default/files/PDFfiles/OPPIPwCReport-Lean Implementation_0.pdf. [Last cited on 2017 Jun 28].

51. Carleysmith SW, Dufton AM, Altria KD. Implementing Lean 
Sigma in pharmaceutical research and development: A review by practitioners. R\&D Manag 2009;39:95-106. Available from: http:// www.3.interscience.wiley.com/journal/121562106/abstract. [Last cited on 2017 Sep 03]

52. Merck Adopts Lean Manufacturing to Slim Down its Supply Chain Costs and Get Closer to the Customer. Somers (NY): IBM Corporation; c2007. Available from: http://www.ftp://ftp.software.ibm.com/ software/solutions/pdfs/ODC00259-USEN-00.pdf. [Last cited on 2017 May 16].

53. Lokesh MS, Gupta NV. Innovare academic sciences quality management system in change control at industry level: An overview. Int J Pharm Pharm Sci 2015;7:1-19. 